\title{
Gender Differences in Early Reading Strategies: A Comparison of Synthetic Phonics Only with a Mixed Approach to Teaching Reading to 4-5 Year-Old Children
}

\author{
Ruth Price-Mohr ${ }^{1} \cdot$ Colin Price $^{2}$
}

Published online: 29 July 2016

(c) The Author(s) 2016. This article is published with open access at Springerlink.com

\begin{abstract}
A survey of primary schools in England found that girls outperform boys in English across all phases (Ofsted in Moving English forward. Ofsted, Manchester, 2012). The gender gap remains an on-going issue in England, especially for reading attainment. This paper presents evidence of gender differences in learning to read that emerged during the development of a reading scheme for 4- and 5-year-old children in which 372 children from Reception classes in sixteen schools participated in 12-month trials. There were three arms per trial: Intervention non-PD (non-phonically decodable text with mixed methods teaching); Intervention PD (phonically decodable text with mixed methods teaching); and a 'business as usual' control condition SP (synthetic phonics and decodable text). Assignment to Intervention condition was randomised. Standardised measures of word reading and comprehension were used. The research provides statistically significant evidence suggesting that boys learn more easily using a mix of whole-word and synthetic phonics approaches. In addition, the evidence indicates that boys learn to read more easily using the natural-style language of 'real' books including vocabulary which goes beyond their assumed decoding ability. At post-test, boys using the nonphonically decodable text with mixed methods (Intervention $\mathrm{A}$ ) were 8 months ahead in reading comprehension
\end{abstract}

Ruth Price-Mohr

rmm519@york.ac.uk; ruthpricemohr@gmail.com

Colin Price

c.price@worc.ac.uk

1 Institute for Effective Education, University of York, York, UK

2 University of Worcester, Worcester, UK compared to boys using a wholly synthetic phonics approach.

Keywords Synthetic phonics - Gender differences ·

Comprehension - Reading $\cdot$ Randomised controlled trial

\section{Introduction}

There is consistent evidence reported in international research that girls outperform boys on measures of reading in all age-groups. In 2008, a study of 15-year olds, in 31 countries worldwide, revealed a gender gap in reading, favouring girls, in all the participating countries (Marks 2008). In the US, this gender gap in reading has been recognised since the 1960s. It is evident as early as first grade and particularly amongst struggling readers (Chatterji 2006; DfES 2009; Robinson and Lubienski 2011). The higher ratio of boys to girls amongst the weakest readers has been found in large-scale assessments internationally (Baye and Monseur 2016; Limbrick et al. 2010) and in England (Rutter et al. 2004; Snowling and Hulme 2012). In this paper, we present first some of the evidence in the literature relating to the gender gap in reading, followed by evidence that there are gender differences in preferences for learning strategies and prior research related to gender and synthetic phonics. We then present the results of the research, analysed according to gender, and discuss the findings as they relate to the synthetic phonics teaching approach that is currently used in schools in England.

According to an Ofsted report published in England in 2012, there was a nine percent difference between girls and boys in reading on the Early Years Foundation Stage Profile (age 5) and an eight percent difference still at the end of Key Stage 2 (age 11) (Ofsted 2012). The phonics 
screening check, introduced in England in 2012, has shown girls' scores approximately eight percent ahead of boys' scores year on year. Currently boys as a group have lower scores for the phonics screening check at age six and generally girls outperform boys in reading at this age (National Literacy Trust 2012; Ofsted 2012; Walker et al. 2014). Girls in England have been reported to outperform boys on tests of reading comprehension and boys outnumber girls as struggling readers (DfE 2013, 2014b; Logan and Johnston 2010; National Literacy Trust 2012). According to data analysed by the National Literacy Trust (2012), girls of this age enjoy reading more than boys and spend more time reading. There is some evidence that more boys than girls from lower SES backgrounds are vulnerable to failure in reading (Jerrim 2013; Nuttall and Doherty 2014). The authors of one report (Nuttall and Doherty 2014), make no mention of any girls in their sample of poor readers from low SES and it is clear that the school from which this report derives were using synthetic phonics as a teaching approach.

There is accumulating evidence in the literature indicating that the gender gap in reading may be associated with differences in the way children approach learning to read. These differences are described in brief below and include learning preferences and differences in memory and information processing.

Gender differences in memory have been found which suggest that boys outperform girls on spatial memory tasks such as abstract visual memory, and girls outperform boys on verbal memory tasks such as digit and object recall (Wei et al. 2012). Boys have been found to perform higher than girls at recalling new words when using captions in combination with narration on television: boys scored higher when there were captions in addition to narration and girls scored higher with narration and no captions (Linebarger 2001). Gender differences have been found in the strategy used in working memory depending on the relative strengths of visuospatial working memory and verbal working memory. There is also evidence to suggest that boys and girls solve problems differently, that boys outperform girls on mental orientation of visual images and that boys prefer visual approaches to learning (Goldstein et al. 2005; Lawton and Hatcher 2005; Lowe et al. 2003; Sagrilo 2013). Children whose visuospatial working memory is dominant are thought to be more likely to use holistic strategies and these are more likely to be boys; children whose verbal working memory is dominant are more likely to use analytic strategies and these are more likely to be girls (Wang and Carr 2014). Synthetic phonics is very much a step-by-step analysis of words rather than a holistic use of whole words or even whole sentences and thus possibly more suited to children using analytic strategies, who are more likely to be girls.
Logan and Johnston (2010) have suggested that boys are not naturally inclined to link phonological and visual information and thus the explicit teaching of this via synthetic phonics may be of benefit. Other research has reported that significantly more girls than boys prefer to use a phonics approach as a strategy to reading unfamiliar words (Beech 2010). The implication here is that boys on the whole show a preference for other learning strategies. Researchers looking at the development of navigational skills, requiring more visuospatial ability than verbal, in 6to 8-year-old children, found that boys out performed girls (Leon et al. 2014). The authors speculate that this difference is caused by differences in hormones which result in dimorphic development of brain structure.

Additionally, gender differences in reading interests suggest that girls are more likely to perform well in passage comprehension of text regardless of content, whereas boys are more likely both to exert themselves and perform better in comprehension if the passage is meaningful to them (Logan and Johnston 2009; McGeown et al. 2015; Oakhill and Petrides 2007). The instructional texts associated with a synthetic phonics approach to teaching reading, often referred to as basal readers, contain a restricted vocabulary which may lead to a lack of authenticity and meaning, with less motivational content for boys (Coles 2004; Hassett 2008; Shannon 2001).

A systematic review of research conducted by Torgerson et al. (2006) found no clear evidence to indicate that the use of phonics teaching affected the gender gap. A study conducted in Clackmannanshire, Scotland (Johnston and Watson 2005) found that synthetic phonics benefitted boys' progress. However, this was only for word decoding and made no impact on reading comprehension. The results from our research presented below, suggest that gender and teaching approach interact most significantly for reading comprehension in young children and that synthetic phonics alone results in lower comprehension scores, particularly for boys.

\section{Theoretical Framework}

There is consensus in the literature that there is a gender gap in reading skills. Two possible theoretical constructs for the gender gap in reading have been presented in brief above. The first is the suggestion that there are gender differences in learning strategy. Differences in reading strategies and response to different teaching approaches between boys and girls were observed in our research. It became apparent that girls were using synthetic-phonics strategies more than boys, and that boys were recognising irregular words as whole words more easily than girls. Thus, one of the aims of the research project was to 
compare word-reading and comprehension outcomes between children taught using a wholly synthetic phonics approach according to the National Curriculum in England (DfE 2013) and children taught using a mix of other approaches in addition to synthetic phonics. We compared boys and girls separately in these two conditions.

The second theoretical construct is that boys rely more on the meaning of text and that there is a motivational element to this. The restricted vocabulary used in basal readers, in which the language is less familiar than in authentic text, may influence comprehension of text. It has been suggested that simplified text is not necessarily easier to understand and that more natural text, even in complex sentences, may be easier to understand (Baumann et al. 2007; Clark 2014). To compare the use of the kind of phonically decodable vocabulary used in basal readers with more naturalistic non-phonically decodable vocabulary, two parallel sets of reading texts and teaching resources were deployed in order to compare boys and girls in these two conditions.

\section{Sample}

The children participating in these studies were from sixteen mainstream state schools from two counties, with a balanced mix of rural and urban schools. All participating children were in either their first or third term of a Reception class on starting the project at pre-test, starting school in the September of 2013. At pre-test the total sample size was three hundred and seventy-two, which was estimated to have $80 \%$ power to detect a minimum effect size of 0.20 . There were small (not statistically significant) numbers of children with English as an additional language in all of the participating schools. Schools in all three sudies were mainstream state schools that would normally follow the National Curriculum (DfE 2013). None of the participating schools had been deemed unsatisfactory by Ofsted. Children in all participating classes (both Control and Intervention) were to continue with their normal curriculum, using statutory synthetic phonics.

\section{Methods}

The study design was a three-armed controlled trial:

- Arm 1: Intervention non-PD (non-phonically decodable vocabulary with mixed teaching methods)

- Arm 2: Intervention PD (phonically decodable vocabulary with mixed teaching methods)
- Arm 3: SP (exclusively synthetic phonics teaching and decodable vocabulary)

A control condition (the SP condition equated to 'business as usual') was used to account for temporal changes and regression to the mean effects (Torgerson and Torgerson 2008). Interventions non-PD and PD were randomised to condition to control for selection bias and to ensure internal validity. Randomisation of allocation was assigned independently at the Institute for Effective Education, University of York, by the data manager. All children were assessed at both pre-test and post-test. Trials lasted for approximately 1 year.

Measures used for this analysis were: the British Picture Vocabulary Scale (BPVS) (Dunn et al. 2009), and from the York Assessment of Reading for Comprehension (YARC), Letter Sound Knowledge (LSK), Early Word Reading (EWR) and Passage Reading Comprehension (PRC) (Snowling et al. 2009). Passage Reading Comprehension was only assessed post-test due to the likelihood of floor effects. Many of the children in this study would have had insufficient word recognition skills at pre-test for this measure, and therefore true differences may not have been observed.

Children in the Intervention schools were taught reading strategies using an eclectic (mixed methods) approach in addition to their synthetic phonics. This was compared to a synthetic-phonics only approach in the Control schools. Teachers were provided with a manual that included detailed lesson plans and guidance for the use of the resources. All the learning materials and books were provided to the schools in advance. Teachers received initial training in the use of the Reading Programme at pre-test to reduce risk of variation (Morris et al. 2000; Tracey et al. 2014), but follow-up support varied for each Study.

\section{Mixed Methods Learning Activities}

With the exception of the introductory and plenary sessions, all activities were designed for group work. This decision was based on strong support in the literature (Abrami et al. 2000; Hatcher et al. 2006; Pickett 1998; Siraj-Blatchford 2009; Slavin et al. 2009; Tracey et al. 2014). Learning through play was a chosen focus throughout, based on the seminal work of Vygotsky (1978) and endorsed by many others in the field (Burnett 2007; Pickett 1998; Stephen 2010; Sylva 1984; Willam 2009). The majority of activities were adaptations of traditional games, and in addition, new games were developed specifically for this research.

A number of activities were designed to extend oral vocabulary (Baumann et al. 2007; Clarke et al. 2010; Fricke et al. 2012; Protopapas et al. 2013), which has been 
found to aid word recognition for words with inconsistent spellings (Hay and Fielding-Barnsley 2009; McGeown and Medford 2014; Ricketts et al. 2007). Increasing oral vocabulary also supports the development of background knowledge used for inference generation needed for comprehension (Clarke 2009; Compton et al. 2014; Garner and Bochna 2004; Graesser et al. 1994; Johnston and Barnes 2008; Ricketts et al. 2011; Snowling and Hulme 2011; Williams 2014). Activities were also designed to build up a sight-word vocabulary as well as extending oral vocabulary as additional support for inference generation (BowyerCrane and Snowling 2005; Elliott and Grigorenko 2014; Snowling and Hulme 2012).

\section{The Instructional Reading Texts}

Two parallel reading schemes were used (Text PD and Text non-PD). Text PD contained only words which should be phonically decodable by children in Reception classes who are following the structured sequence of phonic sounds as set out in the National Curriculum (DfE $2014 a, b)$. Text non-PD was designed to replicate the kind of language used in 'real' books, with no restrictions in the choice of vocabulary other than being age appropriate and congruent with Text PD. Both texts used repetition and introduced the same number of words per book, having the same length of sentences, and the same number of pages as well as having identical illustrations. These criteria have been used in similar analyses of reading texts (Jenkins et al. 2004; Mesmer 2009).

\section{Results}

The outcomes reported are the mean scores using standardised measures (the British Picture Vocabulary Scale, Letter Sound Knowledge, Early Word Reading and Passage Reading Comprehension). Intention-to-treat analysis was used; however, data from individuals for whom no post-test data were available, having been lost to follow up, were excluded from the analyses and considered to be missing at random. For each of the measures, independent samples $t$ tests were carried out on the data and effect sizes calculated (Cohen's $d$ ) and reported in terms of months reading progress (Higgins et al. 2013). Standard scores are reported throughout to control for age and are detailed in Tables 1, 2, 3 and 4 .

The gender balance was different in all three arms, with the Control group having $6 \%$ more girls, Intervention PD having equal percentages, and Intervention non-PD having $16 \%$ more boys.

For the British Picture Vocabulary Scale measure (see Table 1), there was little change in the gender gap over time for the SP condition, with a significant difference between girls and boys at both times, girls scoring approximately 7 months ahead of boys at both times. There were also no changes in either of the Intervention arms, suggesting that there was no effect from the Intervention for this measure.

For Letter Sound Knowledge (see Table 2), the gender gap narrowed slightly for the SP condition, but more so for Intervention non-PD. Boys in Intervention non-PD made greater gains than any other group and boys in Intervention PD made the least progress. For girls, there was little difference in pre-post effect sizes. Between non-PD and PD this was $d=0.04$; between $\mathrm{PD}$ and $\mathrm{SP} d=0.01$; and between non-PD and SP $d=0.05$. There were greater differences for boys. Between non-PD and PD this was $d=0.61$ (7 months); between $\mathrm{PD}$ and SP $d=0.30$ (4 months in favour of the SP group); and between non-PD and SP $d=0.31$ (4 months). For this measure Intervention non-PD appears to have had a positive impact on mean scores for boys.

For Early Word Reading (see Table 3) the gender gap widened for all arms of the trial, with both boys and girls in Intervention non-PD making greater gains than either of the other two arms of the trial. For girls, there were greater differences in pre-post effect sizes between the trial arms for this measure compared to the other measures. Between non-PD and PD this was $d=0.23$ (3 months); between PD and SP $d=0.06$; and between non-PD and SP $d=0.29$ (4 months). For boys, the differences were similar to the girls. Between non-PD and $\mathrm{PD}$ this was $d=0.21$ (3 months); between PD and SP $d=0.08$; and between non-PD and SP $d=0.29$ (4 months). For this measure Intervention non-PD appears to have had a positive impact on mean scores for girls and boys.

For the Passage Reading Comprehension measure (see Table 4), which was only assessed at post-intervention, there was both a statistically significant difference in the SP condition between boys and girls $(p=.032)$ and an effect size of $d=0.41$ ( 5 months difference). For Intervention PD, the difference was not statistically significant but there was an effect size of $d=0.43$ (5 months difference). Intervention non-PD had the narrowest gender gap, with an effect size of $d=0.11$, equivalent to less than 2 months difference. For girls, the difference in pre-post effect sizes between trial arms was less than for boys. Between non-PD and PD this was $d=0.16$ (2 months); between PD and SP $d=0.20$ (3 months); and between non-PD and SP $d=0.35$ (4 months). For boys, the difference between trial arms was greatest for this measure. Between non-PD and PD this was $d=0.46$ (6 months); between $\mathrm{PD}$ and $\mathrm{SP} d=0.26$ (3 months); and between non-PD and SPl $d=0.68$ (8 months). For this measure, Intervention non-PD had the greatest positive impact on mean scores for boys. 
Table 1 Means, standard deviations, significance and effect sizes of gender at pre and post-test for the British Picture Vocabulary Scale (BPVS)

\begin{tabular}{|c|c|c|c|c|c|c|c|}
\hline Condition & Gender & $\begin{array}{l}\text { Mean Time } 1 \\
\text { (SD) }\end{array}$ & $\begin{array}{l}\text { Mean Time } 2 \\
\text { (SD) }\end{array}$ & $\begin{array}{l}\text { Sig. }(p) \text { Time } \\
1\end{array}$ & $\begin{array}{l}\text { Sig. ( } p \text { ) Time } \\
2\end{array}$ & $\begin{array}{l}\text { Cohen's } d \text { Time } \\
1\end{array}$ & $\begin{array}{l}\text { Cohen's } d \text { Time } \\
2\end{array}$ \\
\hline \multirow[t]{2}{*}{ SP } & $\mathrm{M}=52$ & 95.15 (13.39) & $93.11(11.61)$ & \multirow[t]{2}{*}{.003} & \multirow[t]{2}{*}{.008} & \multirow[t]{2}{*}{0.57} & \multirow[t]{2}{*}{0.51} \\
\hline & $F=58$ & $102.84(13.23)$ & 99.08 (11.67) & & & & \\
\hline \multirow[t]{2}{*}{ Intervention non-PD } & $M=59$ & 103.57 (11.44) & $100.50(12.32)$ & \multirow[t]{2}{*}{.350} & \multirow[t]{2}{*}{.443} & \multirow[t]{2}{*}{0.18} & \multirow[t]{2}{*}{0.15} \\
\hline & $F=43$ & $105.81(12.47)$ & $102.25(9.75)$ & & & & \\
\hline \multirow[t]{2}{*}{ Intervention PD } & $\mathrm{M}=37$ & 104.75 (11.77) & $100.54(12.19)$ & \multirow[t]{2}{*}{.669} & \multirow[t]{2}{*}{.965} & \multirow[t]{2}{*}{-0.09} & \multirow[t]{2}{*}{-0.01} \\
\hline & $\mathrm{F}=37$ & $103.62(10.92)$ & $100.43(8.80)$ & & & & \\
\hline \multirow{2}{*}{$\begin{array}{l}\text { Combined } \\
\text { interventions }\end{array}$} & $M=96$ & $104.03(11.52)$ & $100.52(12.21)$ & \multirow[t]{2}{*}{.663} & \multirow[t]{2}{*}{.593} & \multirow[t]{2}{*}{0.06} & \multirow[t]{2}{*}{0.08} \\
\hline & $F=80$ & $104.80(11.76)$ & $101.41(9.31)$ & & & & \\
\hline
\end{tabular}

Table 2 Means, standard deviations, significance and effect sizes of gender at pre and post-test for Letter Sound Knowledge (LSK)

\begin{tabular}{|c|c|c|c|c|c|c|c|}
\hline Condition & Gender & $\begin{array}{l}\text { Mean Time } 1 \\
\text { (SD) }\end{array}$ & $\begin{array}{l}\text { Mean Time } 2 \\
\text { (SD) }\end{array}$ & $\begin{array}{l}\text { Sig. (p) Time } \\
1\end{array}$ & $\begin{array}{l}\text { Sig. }(p) \text { Time } \\
\text { Pime }\end{array}$ & $\begin{array}{l}\text { Cohen's } d \text { Time } \\
1\end{array}$ & $\begin{array}{l}\text { Cohen's } d \text { Time } \\
2\end{array}$ \\
\hline \multirow[t]{2}{*}{ SP } & $\mathrm{M}=52$ & $104.86(17.01)$ & $114.05(15.43)$ & \multirow[t]{2}{*}{.318} & \multirow[t]{2}{*}{.474} & \multirow[t]{2}{*}{0.19} & \multirow[t]{2}{*}{0.13} \\
\hline & $\mathrm{F}=58$ & $108.00(15.72)$ & $116.03(13.40)$ & & & & \\
\hline \multirow[t]{2}{*}{ Intervention non-PD } & $\mathrm{M}=59$ & $106.59(16.71)$ & $118.76(10.50)$ & \multirow[t]{2}{*}{.100} & \multirow[t]{2}{*}{.679} & \multirow[t]{2}{*}{0.33} & \multirow[t]{2}{*}{0.08} \\
\hline & $F=43$ & $112.06(16.03)$ & $119.55(8.04)$ & & & & \\
\hline \multirow[t]{2}{*}{ Intervention PD } & $\mathrm{M}=37$ & $112.02(14.85)$ & $115.78(13.04)$ & \multirow[t]{2}{*}{.616} & \multirow[t]{2}{*}{.447} & \multirow[t]{2}{*}{-0.11} & \multirow[t]{2}{*}{0.17} \\
\hline & $\mathrm{F}=37$ & $110.21(16.09)$ & 117.97 (11.53) & & & & \\
\hline \multirow{2}{*}{$\begin{array}{l}\text { Combined } \\
\text { interventions }\end{array}$} & $M=96$ & $108.68(16.16)$ & 117.61 (11.57) & \multirow[t]{2}{*}{.301} & \multirow[t]{2}{*}{.460} & \multirow[t]{2}{*}{0.15} & \multirow[t]{2}{*}{0.11} \\
\hline & $\mathrm{F}=80$ & $111.21(15.98)$ & $118.82(9.78)$ & & & & \\
\hline
\end{tabular}

Table 3 Means, standard deviations, significance, and effect sizes of gender at pre and post-test for Early Word Reading (EWR)

\begin{tabular}{|c|c|c|c|c|c|c|c|}
\hline Condition & Gender & $\begin{array}{l}\text { Mean Time } 1 \\
\text { (SD) }\end{array}$ & $\begin{array}{l}\text { Mean Time } 2 \\
\text { (SD) }\end{array}$ & $\begin{array}{l}\text { Sig. }(p) \text { Time } \\
1\end{array}$ & $\begin{array}{l}\text { Sig. (p) Time } \\
2\end{array}$ & $\begin{array}{l}\text { Cohen's } d \text { Time } \\
1\end{array}$ & $\begin{array}{l}\text { Cohen's } d \text { Time } \\
2\end{array}$ \\
\hline \multirow[t]{2}{*}{ SP } & $M=52$ & $97.55(12.65)$ & $105.92(16.55)$ & \multirow[t]{2}{*}{.622} & \multirow[t]{2}{*}{.385} & \multirow[t]{2}{*}{0.09} & \multirow[t]{2}{*}{0.16} \\
\hline & $\mathrm{F}=58$ & $98.72(12.09)$ & $108.43(13.55)$ & & & & \\
\hline \multirow[t]{2}{*}{ Intervention non-PD } & $\mathrm{M}=59$ & $99.91(13.22)$ & $110.96(12.48)$ & \multirow[t]{2}{*}{.658} & \multirow[t]{2}{*}{.118} & \multirow[t]{2}{*}{0.08} & \multirow[t]{2}{*}{0.31} \\
\hline & $F=43$ & $101.13(14.40)$ & $114.79(11.51)$ & & & & \\
\hline \multirow[t]{2}{*}{ Intervention PD } & $\mathrm{M}=37$ & 96.94 (11.98) & $106.02(15.86)$ & \multirow[t]{2}{*}{.231} & \multirow[t]{2}{*}{.118} & \multirow[t]{2}{*}{0.28} & \multirow[t]{2}{*}{0.36} \\
\hline & $\mathrm{F}=37$ & $100.48(13.20)$ & $111.51(13.89)$ & & & & \\
\hline \multirow{2}{*}{$\begin{array}{l}\text { Combined } \\
\text { interventions }\end{array}$} & $\mathrm{M}=96$ & 98.77 (12.78) & $109.06(14.01)$ & \multirow[t]{2}{*}{.304} & \multirow[t]{2}{*}{.040} & \multirow[t]{2}{*}{0.15} & \multirow[t]{2}{*}{0.31} \\
\hline & $\mathrm{F}=80$ & $100.83(13.77)$ & 113.27 (12.69) & & & & \\
\hline
\end{tabular}

Taken together, the results suggest that boys in Intervention non-PD have made more progress than boys in either of the other arms across all three trials for Letter Sound Knowledge, Early Word Reading and Passage Reading Comprehension.

At post-test, girls scored higher than boys for all measures in all arms of the trial. Intervention non-PD, which had a larger number of boys, nevertheless showed higher mean scores than the other arms of the trial on Letter Sound
Knowledge, Early Word Reading and Passage Reading Comprehension. In addition, boys in Intervention non-PD had higher mean scores than boys in the other arms on these three measures. These results suggest that the use of non-phonically decodable vocabulary with mixed teaching methods had a positive impact on these measures for all children and particularly for boys. Results also suggest a positive effect for boys from using the mixed methods teaching in the Intervention in respect of their Early Word 
Table 4 Means, standard deviations, significance and effect sizes of gender at post-test for Passage Reading Comprehension (PRC)

\begin{tabular}{lllll}
\hline Condition & Gender & Mean Time 2 (SD) & Sig. $(p)$ Time 2 only & Effect size (Cohen's $d$ ) Time 2 only \\
\hline SP & $\mathrm{M}=52$ & $94.80(8.84)$ & .032 & 0.41 \\
& $\mathrm{~F}=58$ & $98.75(10.03)$ & & 0.11 \\
Intervention non-PD & $\mathrm{M}=59$ & $101.15(9.66)$ & .577 & 0.43 \\
Intervention PD & $\mathrm{F}=43$ & $102.23(9.57)$ & .065 & 0.21 \\
& $\mathrm{M}=37$ & $97.02(8.21)$ & .162 & \\
Combined interventions & $\mathrm{F}=37$ & $100.70(8.65)$ & & \\
& $\mathrm{M}=96$ & $99.56(9.30)$ & $101.52(9.13)$ & \\
\hline
\end{tabular}

Reading and Passage Reading Comprehension. Overall, the Intervention group showed mean scores which exceeded those in the comparison group (with the exception of Intervention PD for Letter Sound Knowledge).

\section{Discussion}

The results reported here show no effect of the Intervention on the gender gap for the British Picture Vocabulary Scale. For Letter Sound Knowledge there was a narrowing of the gender gap (boys catching up with girls) in Intervention non-PD. For Early Word Reading the gender gap increased for children in Intervention non-PD and PD, although boys in both arms nevertheless outperformed boys in the SP condition. For Passage Reading Comprehension the gender gap was similar between Intervention PD and the SP condition and smallest in Intervention non-PD.

Overall, girls in this study seem to have benefitted most from the use of non-decodable vocabulary, and boys seem to have benefitted from both the mixed teaching methods and the non-decodable vocabulary used. There was a positive impact from the use of non-decodable vocabulary and mixed teaching methods in addition to synthetic phonics on both word decoding and reading comprehension.

Within the Synthetic Phonics condition, the gender gap (girls doing better than boys) was observed for all the measures used. By contrast, the results presented here indicate that a narrower gender gap is associated with a mixed approach to teaching methods, and with the use of more complex vocabulary which goes beyond a child's current decoding ability. This was particularly noticeable for reading comprehension. This research shows that Reception-age children and boys in particular, make more progress in reading through the use of a more eclectic approach to the teaching of reading than is currently being advocated in schools. There was no evidence in any of these studies that children were confused by using more than one strategy to read. The preference of girls to sound out words, as observed by others (Beech 2010), was also observed during assessments in these trials, as was the preference for boys to use a whole-word strategy.

In conclusion, synthetic phonics clearly has a place in the classroom but this should not be the sole approach to teaching reading to all children and boys in particular. Instead a more balanced approach should be taken whereby children are taught additional strategies including the use of whole-word and more visual techniques. Perhaps more importantly, the instructional texts young children are given to read should reflect the more natural language of 'real' books.

Ethical Approval All procedures performed in studies involving human participants were in accordance with the ethical standards of the institutional and/or national research committee and with the 1964 Helsinki declaration and its later amendments or comparable ethical standards. Informed consent was obtained from all individual participants included in the studies.

Open Access This article is distributed under the terms of the Creative Commons Attribution 4.0 International License (http://crea tivecommons.org/licenses/by/4.0/), which permits unrestricted use, distribution, and reproduction in any medium, provided you give appropriate credit to the original author(s) and the source, provide a link to the Creative Commons license, and indicate if changes were made.

\section{References}

Abrami, P. C., Lou, Y., Chambers, B., Poulsen, C., \& Spence, J. C. (2000). Why should we group students within-class for learning? Educational Research and Evaluation: An International Journal on Theory and Practice, 6(2), 158-179.

Baumann, J. F., Ware, D., \& Carr Edwards, E. (2007). "Bumping into spicy, tasty words that catch your tongue": A formative experiment on vocabulary instruction. The Reading Teacher, 61(2), 108-122.

Baye, A., \& Monseur, C. (2016). Gender differences in variability and extreme scores in an international context. Large-scale Assessments in Education, 4(1), 1. doi:10.1186/s40536-015-0015-x. 
Beech, J. R. (2010). Young readers' strategic approaches to reading unfamiliar words in text. Reading and Writing Quarterly: Overcoming Learning Difficulties, 26(3), 264-284.

Bowyer-Crane, C., \& Snowling, M. J. (2005). Assessing children's inference generation: What do tests of reading comprehension measure? British Journal of Education Psychology, 75, 189-201.

Burnett, J. (2007). A pleasurable path to literacy: Can Steiner contribute to the literacy debate? Journal of Early Childhood Literacy, 7(3), 321-331.

Chatterji, M. (2006). Reading achievement gaps, correlates, and moderators of early reading achievement: Evidence from the Early Childhood Longitudinal Study (ECLS) Kindergarten to first grade sample. Journal of Educational Psychology, 98(3), 489-507.

Clark, M. M. (2014). Learning to be literate. Birmingham: Glendale Education.

Clarke, L. J. (2009). Inference generation and reading disability. Unpublished Doctoral Thesis, University of York, 2009.

Clarke, P., Snowling, M. J., Truelove, E., \& Hulme, C. (2010). Ameliorating children's reading-comprehension difficulties: A randomised controlled trial. Psychological Science, 20(10), $1-11$.

Coles, G. (2004). Real books in the caboose. Knowledge Quest, 33(2), 22-25.

Compton, D. L., Miller, A. C., Ellenan, A. M., \& Steacy, L. M. (2014). Have we forsaken reading theory in the name of "quick fix" interventions for children with reading disability? Scientific Studies of Reading, 18(1), 55-73.

Department for Education. (2014). National curriculum assessments at key stage 2. London: HMSO.

Department for Education [DfE]. (2012). Early years foundation stage, Department for Education. London: HMSO. https://www. education.gov.uk/publications/standard/AllPublications/Pages/ DFE-OOO23-2012

Department for Education [DfE]. (2013). Phonics screening check and national curriculum assessments at key stage 1 in England 2012/13. London: HMSO.

Department for Education [DfE]. (2014). National curriculum for english key stages 1 and 2. London: HMSO.

Department for Education \& Skills [DfES]. (2009). Gender and education: The evidence on pupils in England. London: HMSO.

Dunn, L. M., Dunn, D. M., Sewell, J., Styles, B., Brzyska, B., Shamsan, Y., et al. (2009). The British picture vocabulary scale (3rd ed.). London: GL Assessment.

Elliott, J. G., \& Grigorenko, E. L. (2014). The dyslexia debate. Cambridge: Cambridge University Press.

Fricke, S., Bowyer-Crane, C., Haley, A. J., Hulme, C., \& Snowling, M. J. (2012). Efficacy of language intervention in the early years. Journal of Child Psychology and Psychiatry, 54(3), 280-290.

Garner, J. K., \& Bochna, C. R. (2004). Transfer of a listening comprehension strategy to independent reading in first-grade students. Early Childhood Education Journal, 32(2), 69-74.

Goldstein, J. M., Jerram, M., Poldrack, R., Anagnoson, R., Breiter, H. C., Makris, N., et al. (2005). Sex differences in prefrontal cortical brain activity during fMRI of auditory verbal working memory. Neuropsychology, 19(4), 509-519.

Graesser, A. C., Singer, M., \& Trabasso, T. (1994). Constructing inferences during narrative text comprehension. Psychological Review, 101(3), 371-395.

Hassett, D. D. (2008). Teacher flexibility and judgement: A multidynamic literacy theory. Journal of Early Childhood Literacy, 8(3), 295-327.

Hatcher, P. J., Hulme, C., Miles, J. N. V., Carroll, J. M., Hatcher, J., Gibbs, S., et al. (2006). Efficacy of small group intervention for beginning readers with reading-delay: A randomised controlled trial. Journal of Child Psychology and Psychiatry, 47(8), $820-827$.

Hay, I., \& Fielding-Barnsley, R. (2009). Competencies that underpin children's transition into early literacy. Australian Journal of Language and Literacy, 32(2), 148-162.

Higgins, S., Katsipataki, M., Kokotsaki, D., Coe, R., Major, L. E., \& Coleman, R. (2013). The Sutton Trust-Education Endowment Foundation teaching and learning toolkit: Technical appendix. London: Education Endowment Foundation.

Jenkins, J. R., Peyton, J. A., Sanders, E. A., \& Vadasy, P. F. (2004). Effects of reading decodable texts in supplemental first-grade tutoring. Scientific Studies of Reading, 8(1), 53-85.

Jerrim, J. (2013). The Reading Gap: The socio-economic gap in children's reading skills: A cross-national comparison using PISA 2009. London: The Sutton Trust.

Johnston, A. M., \& Barnes, M. A. (2008). Reading comprehension: Developmental processes, individual differences and interventions. Canadian Psychology, 49(2), 125-132.

Johnston, R. S., McGeown, S., \& Watson, J. E. (2012). Long-term effects of synthetic versus analytic phonics teaching on the reading and spelling ability of 10 year old boys and girls. Reading and Writing, 25, 1365-1384.

Johnston, R. S., \& Watson, J. E. (2005). A seven year study of the effects of synthetic phonics teaching on reading and spelling attainment. Insight 17, Scottish Executive Education Department, Edinburgh: SEED.

Kendeou, P., Savage, R., \& van den Broek, P. (2009). Revisiting the simple view of reading. British Journal of Educational Psychology, 79, 353-370.

Lawton, C. A., \& Hatcher, D. W. (2005). Gender differences in integration of images in visuospatial memory. Sex Roles, 53(9/ 10), 717-725.

Leon, I., Cimadevilla, J. M., \& Tascon, L. (2014). Developmental gender differences in children in a virtual spatial memory task. Neuropsychology, 28(4), 485-495.

Limbrick, L., Wheldall, K., \& Madelaine, A. (2010). Estimating gender ratios of poor reading using large-scale assessments. Australian Journal of Education, 54(2), 190-222.

Linebarger, D. L. (2001). Learning to read from television: The effects of using captions and narration. Journal of Educational Psychology, 93(2), 288-298.

Logan, S., \& Johnston, R. (2009). Gender differences in reading ability and attitudes: Examining where these differences lie. Journal of Research in Reading, 32(2), 199-214.

Logan, S., \& Johnston, R. (2010). Investigating gender differences in reading. Educational Review, 62(2), 175-187.

Lowe, P. A., Mayfield, J. W., \& Reynolds, C. R. (2003). Gender differences in memory test performance among children and adolescents. Archives of Clinical Neuropsychology, 18, 865-878.

Marks, G. N. (2008). Accounting for the gender gaps in student performance in reading and mathematics: Evidence from 31 countries. Oxford Review of Education, 34(1), 89-109.

McGeown, S. P., Johnston, R. S., Walker, J., Howatson, K., Stockburn, A., \& Dufton, P. (2015). The relationship between young children's enjoyment of learning to read, reading attitudes, confidence and attainment. Educational Research, 57(4), 389-402.

McGeown, S. P., \& Medford, E. (2014). Using method of instruction to predict the skills supporting initial reading development: Insight from a synthetic phonics approach. Reading and Writing, 27(3), 591-608.

Mesmer, H. A. E. (2009). Textual scaffolds for developing fluency in beginning readers: Accuracy and reading rate in qualitatively levelled and decodable text. Literacy Research and Instruction, 49(1), 20-39. 
Morris, D., Tyner, B., \& Perney, J. (2000). Early steps: Replicating the effects of a first-grade reading intervention program. Journal of Educational Psychology, 92(4), 681-693.

National Literacy Trust. (2012). Boy's Reading Commission. London: National Literacy Trust.

Nuttall, A., \& Doherty, J. (2014). Disaffected boys and the achievement gap: 'The wallpaper effect' and what is hidden by a focus on school results. Urban Review, 46, 800-815.

Oakhill, J. V., \& Petrides, A. (2007). Sex differences in the effects of interest on boys' and girls' reading comprehension. British Journal of Psychology, 98, 223-235.

Ofsted. (2012). Moving English forward. Manchester: Ofsted.

Pickett, L. (1998). Literacy learning during block play. Journal of Research in Childhood Education, 12(2), 225-230.

Protopapas, A., Mouzaki, A., Sideridis, G. D., Kotsolakou, A., \& Simos, P. G. (2013). The role of vocabulary in the context of the simple view of reading. Reading and Writing Quarterly: Overcoming Learning Difficulties, 29(2), 168-202.

Ricketts, J., Bishop, D. V. M., Pimperton, H., \& Nation, K. (2011). The role of self-teaching in learning orthographic and semantic aspects of new words. Scientific Studies of Reading, 15(1), 47-70.

Ricketts, J., Nation, K., \& Bishop, D. V. M. (2007). Vocabulary is important for some, but not all reading skills. Scientific Studies of Reading, 11(3), 235-257.

Robinson, J. P., \& Lubienski, S. T. (2011). The development of gender achievement gaps in mathematics and reading during elementary and middle school: examining direct cognitive assessments and teacher ratings. American Educational Research Journal, 48(2), 268-302.

Rutter, M., Caspi, A., Fergusson, D., Horwood, L. J., Goodman, R., Maughen, B., et al. (2004). Sex differences in developmental reading disability. Journal of the American Medical Association, 291(16), 2007-2012.

Sagrilo, M. C. P. (2013). Difference between verbal and visual span in genders: Pilot study. Revista. CEFAC, 15(3), 552-560.

Shannon, P. (2001). Basal readers: Three perspectives. Theory into Practice, 28(4), 235-239.

Siraj-Blatchford, I. (2009). Conceptualising progression in the pedagogy of play and sustained shared thinking in early childhood education: A Vygotskian perspective. Educational and Child Psychology, 26(2), 77-89.

Slavin, R. E., Lake, C., Chambers, B., Cheung, A., \& Davis, S. (2009). Effective reading programs for the elementary grades: A best-evidence synthesis. Review of Educational Research, 79(4), 1391-1466.

Snowling, M. J., \& Hulme, C. (2011). Evidence-based interventions for reading and language difficulties: Creating a virtuous circle. British Journal of Educational Psychology, 81, 1-23.

Snowling, M. J., \& Hulme, C. (2012). Children's reading impairments: From theory to practice. Japanese Psychological Research, 55(2), 186-202.

Snowling, M., Stothard, S. E., Clarke, P., Bowyer-Crane, C., Harrington, A., Truelove, E., et al. (2009). York Assessment of Reading for Comprehension. London: GL Assessment.

Stephen, C. (2010). Pedagogy: The silent partner in early years learning. Early Years, 30(1), 1-14.

Sylva, K. (1984). A hard-headed look at the fruits of play. Early Child Development and Care, 15(2), 171-183.

Torgerson, C. J., Brookes, G., \& Hall, J. (2006). A systematic review of the research literature in the use of phonics in the teaching of reading and spelling. London: Department for Education and Skills (DfES).

Torgerson, D. J., \& Torgerson, C. J. (2008). Designing randomised trials. New York: Palgrave Macmillan.

Tracey, L., Chambers, B., Slavin, R. E., Hanley, P., \& Cheung, A. (2014). Success for All in England: Results from the third year of a national evaluation. York: University of York, Institute for Effective Education.

Vygotsky, L. (1978). The role of play in development, mind in society. Cambridge, MA: Harvard University Press.

Walker, M., Bartlett, S., Betts, H., Sainsbury, M., \& Worth, J. (2014). Phonics screening check evaluation. London: National Foundation for Educational Research, NFER.

Wang, L., \& Carr, M. (2014). Working memory and strategy use contribute to gender differences in spatial ability. Educational Psychologist, 49(4), 261-282.

Wei, W., Lu, H., Zhao, H., Chen, C., Dong, Q., \& Zhou, X. (2012). Gender differences in children's arithmetic performance are accounted for by gender differences in language ability. Psychological Science, 23(3), 320-330.

Willam, J. (2009). Revisiting Susan Isaacs-A modern educator for the twenty-first century. International Journal of Early Years Education, 17(2), 151-165.

Williams, J. C. (2014). Recent official policy and concepts of reading comprehension and inference: The case of England's primary curriculum. Literacy, 48(2), 95-102. 